ks. Pawet Kiejkowski

Uniwersytet im. Adama Mickiewicza w Poznaniu

\title{
Pneumatologiczny rys paschalnej antropologii Wacława Hryniewicza
}

\section{PNEUMATOLOGICAL ASPECT OF WACŁAW HRYNIEWICZ'S PASCHAL ANTHROPOLOGY}

The question of understanding man is the key one in the theological output of Rev. Wacław Hryniewicz, one of the outstanding contemporary Polish theologians. For about twenty years he has been identified as a great promoter of Christian hope, understood as the hope for universal salvation. This universal concept of hope contains a particular vision of both God and an individual. The Lublin scholar is convinced that an authentic anthropological reflection should be inspired by the central truth of Christianity, which is the Passover. This truth pervades all the dimensions of human life and all man's actions. That is why Hryniewicz defines his theology of man as paschal theology. In the deep mystery of the Passover Christ is a great commentator of the mystery of man. The gift of being human, the way towards its fullness and renewal is particularly related to the gift of the Holy Spirit that is present and acts within the mystery of the Church. Influenced by the Eastern Christianity tradition, Hryniewicz much emphasizes the pneumatological dimension of the mystery of the new existence an individual receives within the Church.

Key words: paschal anthropology, pneumatology, Orthodox faith, Holy Spirit.

\section{Paschalna antropologia W. Hryniewicza}

Pytanie o człowieka należy do najważniejszych spośród podejmowanych przez współczesne nauki, zwłaszcza humanistyczne, różnorodne kierunki filozoficzne, wielkie religie świata. Znajduje się ono także 
Antropologia teologiczna

w samym centrum chrześcijańskiej teologii. Pytanie o zrozumienie człowieka należy do najważniejszych w bogatym dorobku naukowym jednego z najwybitniejszych i najbardziej oryginalnych współczesnych polskich teologów ks. prof. Wacława Hryniewicza OMI. Ten wielki pasjonat teologii, wybitny ekumenista, wyrazisty, a czasami wręcz kontrowersyjny w swoich poglądach i mocnych sformułowaniach teolog, wieloletni wykładowca Katolickiego Uniwersytetu Lubelskiego, kierownik II Katedry Teologii Dogmatycznej, a następnie Katedry Teologii Prawosławnej, współtwórca i kierownik Instytutu Ekumenicznego KUL, od ponad 20 lat kojarzony jest przede wszystkim jako wielki orędownik chrześcijańskiej nadziei, zwłaszcza w jej wymiarze eschatycznym jako nadziei na powszechne zbawienie. Nie chodzi tu W. Hryniewiczowi tylko o teologiczne spekulacje na temat cnoty nadziei ale o osobiste zatroskanie, aby jako chrześcijanin i kapłan promieniować nadzieją i dawać ją każdemu, choćby najbardziej zagubionemu, człowiekowi. Komentując, opublikowaną korespondencję prowadzoną ze swoimi czytelnikami, pisał:

Teologia wyrasta z życia. Powinna towarzyszyć ludziom na ich, nieraz zawiłych i trudnych, drogach. Kiedy traci więź z życiem, staje się jedynie namiastką przekazu żywej wiary. Zajmuje się problemami, które nikogo nie obchodzą. Odpowiada na pytania, których nikt nie zadaje. Nie uczy wierzących, jak wciąż na nowo odkrywać drogę do tajemnicy Boga w dziejach świata, Kościoła i własnego życia. Zadaniem teologa jest przejmować się ludzkimi troskami i zmaganiami. To wyraz jego głębokiej solidarności z ludźmi ${ }^{1}$.

Zaangażowanie w głoszenie chrześcijańskiej nadziei w ostateczny i fundamentalny sposób związane jest z szacunkiem i troską o konkretnego człowieka, o jego życie naznaczone radością i cierpieniem, o poszukiwanie miłości, sensu, celu, pełni życia². Trzeba jednocześnie przyznać, że uniwersalistyczna nadzieja zakłada określoną wizję Boga oraz człowieka. Na tysiącach stron Hryniewiczowskich tekstów znajdujemy bardzo solidną i niezwykle ciekawą, często pasjonującą i oryginalną, czasami budzącą pytania i kontrowersję, myśl antropologiczną.

W. Hryniewicz, Nadzieja w dialogu. Korespondencja z czytelnikami (1976-2006), Warszawa 2007, s. 511.

Wspominając jeden z listów, w którym jego autor opisuje swoją drogę odnalezienia na nowo miłości Boga, Jezusa, ludzi, życia dzięki przeczytaniu książki Nadzieja zbawienia dla wszystkich, lubelski teolog napisał: „To mnie przekonuje. Warto było napisać tę książkę choćby dla tego jednego człowieka. Warto dawać ludziom nadzieję. Ona jest potrzebna." Nad przepaściami wiary. Z ks. Wacławem Hryniewiczem OMI rozmawiaja Elżbieta Adamiak i Józef Majewski, Kraków 2001, s. 105. 
Lubelski profesor jest przekonany, że autentyczna refleksja antropologiczna powinna czerpać swoje inspiracje z centralnej prawdy chrześcijaństwa - Paschy Chrystusa. To ona przenika wszystkie wymiary ludzkiego życia i wszelkie działania człowieka. Stąd uprawianą przez siebie teologię o człowieku nazywa antropologią paschalną ${ }^{3}$. Chrystus w wielkiej tajemnicy swojej Paschy jest wielkim Interpretatorem tajemnicy człowieka. A samego człowieka można nazwać homo paschalis. Światło Paschy Chrystusa przyjmowane w wierze najowocniej pomaga zinterpretować tajemnicę bytu i egzystencji człowieka w jego wymiarze osobowym i społecznym. Paschalna antropologia wpisuje się w paschalną logikę całego chrześcijaństwa, którą wyznacza tajemnica śmierci i zmartwychwstania Chrystusa, istotnie związane z darem Ducha Świętego. Jest to pascha Wcielonego Syna Bożego zanurzona w tajemnicy miłości Trójjedynego Boga, stanowiąc punkt centralny ekonomii zbawienia, realizującej się w historii świata i ludzkości w mocy Ducha Świętego. W bogatej i wielowątkowej myśli antropologicznej autora trylogii paschalnej warto podkreślić obecność, zwłaszcza niektórych tematów. Hryniewiczowska wizja człowieka jest głęboko teologiczna, chrystologiczna, pneumatologiczna oraz paschalna. Jawi się przed nami człowiek stworzony z Bożej miłości i który spełnia się kochając, trwając w Bożej miłości. Jako osoba jest on ukoronowaniem stworzenia, jest bytem cielesno-duchowym, obdarzony najwyższą godnością, a zarazem kruchy, ograniczony i śmiertelny. Ideą przewodnią, wokół której zebrane są inne tematy, jest prawda o stworzeniu człowieka na obraz i podobieństwo Boże. Ostatecznie oznacza to stworzenie człowieka na obraz Jezusa Chrystusa, który jest obrazem Boga Niewidzialnego. Głęboko biblijna i patrystyczna prawda o ikoniczności człowieka została uzupełniona, ważnymi szczególnie dla tradycji wschodniej, kategoriami człowieka jako mikrotheos i mikrokosmos, homo capax Dei et capax spei, Bogoczłowieczeństwo i eros. Co trzeba podkreślić, jest to wizja wybitnie personalistyczna i dynamiczna, która ukazuje człowieka jako istotę osobową, relacyjną, ekstatyczną, komuniją, epikletyczną, zakorzenioną etycznie, obdarzoną dramatycznym darem wolności oraz ukierunkowaną na eschatyczne spełnienie. Jest to wizja dotycząca każdego konkretnego człowieka, wierzącego i niewierzącego, pełna szacunku wobec każdego z nich, jego wielkości i tajemnicy, poszukiwań i pragnień, nadziei i wątpliwości, a także zagubienia, słabości i grzechu.

Por. M.Rusecki,Antropologia paschalna (homo paschalis), [w:]P. Kantyka(red.), Instaurare omnia in Christo. Ozbawieniu, teologii, dialogu i nadziei profesorowi Wacławowi Hryniewiczowi OMI w 70. rocznicę urodzin, Lublin 2006, s. 289-298. 
Antropologia teologiczna

\section{Pneumatologiczny wątek paschalnej antropologii W. Hryniewicza}

Paschalna droga wewnętrznej przemiany człowieka, jego odnowienia i usynowienia, w szczególny sposób związana jest z darem Ducha Świętego obecnego i udzielającego się w misterium Kościoła. Wacław Hryniewicz pod wpływem tradycji wschodniego chrześcijaństwa ${ }^{4}$, mocno akcentuje pneumatologiczny wymiar tajemnicy nowej egzystencji otrzymywanej w Kościele. Choć koniecznie trzeba pamiętać, że teologia jako nauka o Bogu, chrystologia i soteriologia, pneumatologia oraz eklezjologia wraz sakramentologią, protologią i eschatologią, w kontekście poszukiwań antropologicznych, domagają się twórczej syntezy. Misteria przez nie badane współistnieją nierozdzielnie i wzajemnie się przenikają, zakorzenione w jednej i niepodzielnej ekonomii zbawienia. My zwrócimy uwagę na wymiar pneumatologiczny nowego człowieka w Hryniewiczowskiej antropologii.

Kościół jest szczególną przestrzenią obecności i zbawczego działania Ducha Świętego, jak to w syntetyczny sposób wyraził już św. Ireneusz: „Gdzie jest Duch Boży, tam i Kościól, i wszelka łaska. Duch zaś jest prawdą"5. Kościół jest ze swej natury miejscem obecności Ducha i Jego zbawczego działania poprzez swoje różnorodne dary. Jednocześnie żadna konkretna wspólnota eklezjalna nie ma wyłączności do posiadania czy ograniczania Ducha Świętego, który działa przed i poza widzialnymi strukturami Kościoła ${ }^{6}$. Uzasadniając prawdę o wolnym dzianiu Ducha Bożego, nasz autor odwoła, co jest znamienne, do słów znamienitego teologa prawosławnego, a swojego osobistego mistrza,

$4 \quad$ Nasz autor nawiązuje do takich znanych teologów i myślicieli prawosławnych jak: P. Evdokimov, J. D. Zizioulas, N. A. Nissiotis, W. Łosski, N. Afanasjew, J. Klinger, B. Bobrinskoy.

$5 \quad$ Św. Ireneusz z Lyonu, Bóg $w$ Ciele $i$ Krwi, wybór tekstów i wprowadzenie H. U. von Balthasar, tłum. W. Myszor, Kraków 2001, s. 63.

„Powszechna obecność i działanie Ducha są nieodłączne od wszechogarniającej obecności zmartwychwstałego Chrystusa. Podkreślmy ponownie: nie musimy zdawać sobie sprawy, że żyjemy w obecności Chrystusa i Ducha Świętego, że są obecni w życiu wszystkich ludzi i w całym stworzeniu. Obecność Ducha nie ogranicza się do jego przemieniającego dziania wewnątrz widzialnej wspólnoty Kościoła. To On działa również w życiu innych ludzi”. W. Hryniewicz, Mądrość nadziei. Boży dar zbawienia dla wszystkich, Warszawa 2010 s. 171. Ten wymiar powszechnego działania Ducha Świętego charakterystyczny jest dla pneumatologii Jana Pawła II, obecnej w jego encyklikach Redemptor hominis, Dominum et Vivifacantem czy Redemptoris misio. Por. J. Dupuis, Chrześcijaństwo i religie. Od konfrontacji do dialogu, tłum. S. Obirek, Kraków 2003,.s. 110-116. 
P. Evdokimova ${ }^{7}$ Kościół pozostaje niewątpliwie szczególną przestrzenią zbawczego udzielania się Ducha Świętego. Oznacza to, że człowiek otrzymuje Ducha Chrystusa, gdy trwa w jedności z Ciałem Chrystusa, Kościołem. We wspólnocie Kościoła wierzący zostaje obdarowany różnorodnymi darami i łaskami Ducha Świętego, jednocześnie Duch Święty prowadzi do Kościoła i wtajemnicza w jego misterium.

Podkreślając powszechny dar Ducha Świętego dla wszystkich ludzi, W. Hryniewicz podejmuje myśl św. Ireneusza. Ten sam Duch, który zstąpił na Chrystusa, został zesłany na całą ziemię, wszystkich ludzi, wszelkie stworzenie ${ }^{8}$. Wielu pisarzy kościelnych uczyło, że Duch Święty jest źródłem wszelkiego prawdziwego poznania. Lubelski profesor przywołuje postać Ambrozjastera, anonimowego autora z IV wieku, który pisał: „wszelka prawda, niezależnie od tego, kto ją wypowiada, pochodzi od Ducha Świętego" ". Średniowieczny teolog Albert Wielki uczył, że Duch Święty jest obecny i działa we wszystkich ludziach. Żaden człowiek nie jest pozbawiony Jego łaski, a wszelka prawda, która jest przedmiotem poznania, pochodzi z Jego inspiracji ${ }^{10}$. „Wszelkie dobro, piękno i cześć oddawana Bogu, niezależnie od tego, gdzie one są obecne, pochodzą od Ducha Świętego. Są znakami Jego obecności. To On jest inspiratorem prawdziwego poznania, wszelkiego dobra, piękna i otwarcia się człowieka ku Bogu"11. Ten powszechny charakter działania Ducha Świętego, zauważa nasz autor, jest istotnie obecny w nauczaniu Soboru Watykańskiego II ${ }^{12}$. Sobór Duchowi Bożemu przypisuje wszelkie inspiracje do odnowy i rozwoju ludzkiej społeczności, oparte na poszanowaniu osoby ludzkiej, na prawdzie, sprawiedliwości, wolności, trosce o dobro wspólne. Duch Święty kieruje biegiem czasu, odnawia oblicze

7 „Istnieje więc jakby pośrednia przestrzeń charyzmatyczna poza Kościołem, w której działają jeszcze sakramenty. Kanoniczna granica restryktywna nie utożsamia się z charyzmatyczną granicą działania Ducha Świętego. [...] Jedynie Duch Święty może przekraczać bariery, nie relatywizując niczego, lecz uzupełniając i łącząc wszystkie aspekty chrześcijańskiej wiary w ich nieskończenie zróżnicowanej pełni”. P. Evdokimov, Prawosławie, tłum. J. Klinger, Warszawa 2003, s. 365-367.

Por. W. Hryniewicz, Pascha Chrystusa w dziejach człowieka i wszechświata. Zarys chrześcijańskiej teologii paschalnej, t. 3, Lublin 1991, s. 130.

Cyt. za: tenże, Mąrość nadziei..., dz. cyt., s. 54 .

Por. tenże, Pascha Chrystusa w dziejach człowieka $i$ wszechświata..., dz. cyt., s. 130; G. D’Onofrio, Historia teologii, t. 2, Epoka średniowieczna, tłum. W. Szymona, Kraków 2005, s. 352-357.

W. Hryniewicz, Mądrość nadziei..., dz. cyt., s. 54.

12 Por. Z. J. Kijas, Traktat o Duchu Świętym i łasce, [w:] Dogmatyka, E. Adamiak, A. Czaja, J. Majewski (red.), t. 4, Warszawa 2007, s. 440-441; 
Antropologia teologiczna

ziemi, opatrznościowo prowadzi ewolucję ${ }^{13}$. On wszystkich ludzi inspiruje i prowadzi ku wewnętrznej wolności oraz wyrzekania się egoizmu. Duch Święty sprawia, że działalność wszystkich ludzi znajduje oparcie $\mathrm{w}$ logice, mocy i skuteczności misterium paschalnego ${ }^{14}$.

„Duch Święty nie jest Duchem Kościoła. Jest i pozostanie na zawsze suwerennym Duchem Bożym, Duchem Chrystusa" "15. Jednoczenie wewnątrz misterium Kościoła Bóg w uprzywilejowany sposób posyła stale Ducha Swojego do ludzkich serc (por. Ga 4, 4-6). Ten, który przenika głębokości Boga (por. 1 Kor 2, 10), nawiązuje więzi z duchem człowieka i, nie zabierając mu wolności, przenika najbardziej intymne obszary ludzkiego biblijnego serca, głębię jego człowieczeństwa, a ciała ludzi czyni swoją świątynią (por. 1 Kor 6, 19). Każdy człowiek jest osobą jedyną w swoim rodzaju, wewnętrznie zróżnicowaną i obdarzoną różnorodnymi darami, własnym niepowtarzalnym doświadczeniem i wrażliwością. Duch Święty jest zdolny wszystko to przeniknąć, udoskonalić i zjednoczyć. Czyni to nie wbrew owej różnorodności czy likwidując ją, ale właśnie poprzez nią i za jej pośrednictwem ${ }^{16}$. Może tego dokonać tylko Duch Chrystusa, który jest Duchem transcendentnym, a jednocześnie immanentnie wszechobecnym, wszystko przenikającym i napełniającym życiem. Jest to Duch, który szanuje ludzką wolność, a zarazem ma moc ją inspirować i przeobrażać od wewnątrz ${ }^{17}$.

Duch Święty jest, podkreśla W. Hryniewicz, nieustannym źródłem nowości w dziejach ludzkości oraz poszczególnego człowieka. Pozostaje On stale Bogiem „Nieznanym”, który w pewien sposób ukrywa swoją obecność w tajemnicy wcielonego Słowa ${ }^{18}$, a daje się rozpoznać jedynie poprzez działanie, które prowadzi ku misterium Syna Bożego. Duch Święty daje prawdziwe poznanie tajemnicy Chrystusa. Jest to

13 Por. Konstytucja duszpasterska o Kościele w świecie wspótczesnym „Gaudium et spes", [w:] Sobór Watykański II, Konstytucje, dekrety, deklaracje, Poznań $2002,26$.

Por. tamże, 22, 38.

$15 \quad$ W. Hryniewicz, Nasza pascha z Chrystusem. Zarys chrześcijańskiej teologii paschalnej, t. 2, Lublin 1997, s. 96; por. W. Hryniewicz, K. Karski, H. Paprocki, Credo. Symbol naszej wiary, Kraków 2009, s. 222-223.

16 Por. Z. J. Kijas, Traktat o Duchu Świętym i łasce..., dz. cyt., s. 361-365; B. Stubenrauch, Pneumatologia - traktat o Duchu Świętym, tłum. P. Lisak, Kraków 1999, s. 70-71.

17 Por. W. Hryniewicz, Nasza pascha z Chrystusem..., dz. cyt., s. 97.

18 W. Hryniewicz nawiązuje tu do wyrażenia sformułowanego przez H. U. von Balthasara, określającego Ducha Świętego Bogiem „Nieznanym po tamtej stronie Słowa". Por. W. Hryniewicz, Nasza pascha z Chrystusem..., dz. cyt., s. 103, zwłaszcza przypis 115 . 
poznanie nie tylko „logiczne” czy „filologiczne” ale „duchowe”, właściwe Ojcom Kościoła, mistykom, świętym, którzy często pozostawali ludźmi niewykształconymi. On, pozostając „Nieznanym” i „Ukrytym”, Antropologia teologiczna przenika głębię ludzkiego człowieczeństwa, odnawiając i kształtując ją na obraz Wcielonego Syna. Duch Święty otwiera i przysposabia człowieka na przyjęcie Słowa, a następnie przeobraża, aby tym, „którzy Je przyjęli, dało moc, aby się stali dziećmi Bożymi” $(\mathrm{J} 1,12)$. Działanie takie związane jest z tajemnicą ludzkiej wolności. Duch Chrystusa przenika najgłębsze i najbardziej intymne osobowe akty człowieka, będąc inspiratorem dla ludzkich wolnych decyzji. „Jest Tym, który wyprzedza i wzywa, uprzedza i pociąga. Ten, który jest zawsze u początków, nie przestaje być równocześnie źródłem nowości i dążenia ku przyszłości, do ostatecznego spełnienia"19. Dzięki Duchowi działającemu w Kościele staje się obecna nowość stworzenia: „Oto czynię wszystko nowe" (Ap 21, 5), dzieła Boga zapoczątkowanego i spełnionego w wydarzeniu Paschy oraz Pięćdziesiątnicy. Duch Chrystusa nieprzerwanie aktualizuje wydarzenia paschalne wobec i dla poszczególnych ludzi, dla Kościoła i całego Kosmosu. To On sprawia, że historyczne, jednorazowe, niepowtarzalne wydarzenie Chrystusa ma wpływ na konkretnego człowieka, który w wolności staje się zdolny przyjąc Jego zbawcze owce. „To, co już dane raz na zawsze, spotyka się z tym, co nieoczekiwane i nowe w dziejach każdego poszczególnego człowieka. [...] Nowość Ducha wprowadza ustawicznie w świat eschatologiczny dynamizm nowego stworzenia" ${ }^{20}$.

Duch Święty jest sprawcą owocnego życia ludzkiego. Autor trylogii paschalnej przypomina intuicje św. Ireneusza, który nazywał Ducha Świętego „Boska rosą” "21, bez której egzystencja człowieka pozostaje jałową, bezużyteczną i bezowocną w uczynki życia wiecznego (por. $\mathrm{J} 15,6)^{22}$. Człowiek stale potrzebuje obrony przed tym, co rani i stara się pozbawić sensu ludzkie istnienie. Takim Obrońcą jest Duch Święty (Parákletos) ${ }^{23}$. Wszelkie dobro, które dokonuje się w ludziach, także tych, którzy znajdują się poza instytucjonalnymi ramami Kościoła, nosi na sobie niewidzialne znamię obecności i działania Ducha Świętego. Odnosi się to do wszelkiej ludzkiej twórczości oraz różnorakich

19 Tamże, s. 103.

20 Tamże, s. 104.

21 „Rosa jest Duch Święty.” Św. Ireneusz z Lyonu, Bóg w Ciele $i$ Krwi..., dz. cyt., s. 63.

$22 \quad$ Por. W. Hryniewicz, Pascha Chrystusa w dziejach człowieka i wszechświata..., dz. cyt., s. 132.

23 Por. H. Pietras, Początki teologii Kościoła, Kraków 2000, s. 244-252. 
Antropologia teologiczna

dziedzin kultury ludzkiej ${ }^{24}$. W tych sformułowaniach W. Hryniewicz znajduje się niewątpliwie pod wpływem autorów prawosławnych, G. Fedotova i P. Evdokimova ${ }^{25}$.

\section{Prawosławne inspiracje w pneumatologicznej antropologii W. Hryniewicza}

Na rozumienie zbawczego działania Ducha Świętego oraz wciąż darowanej przez Niego nowości w życiu człowieka i chrześcijanina $\mathrm{w}$ teologii W. Hryniewicza niewątpliwie istotny wpływ miała tradycja wschodnia. Temat ten był przedmiotem jego osobistych poszukiwań, których owocem jest kilka książek opublikowanych na przestrzeni kilkudziesięciu lat jego pracy naukowej ${ }^{26}$. Zdaniem lubelskiego autora, zaduma nad tajemnicą człowieczeństwa należy do charakterystycznych i istotnych rysów pneumatologii prawosławnej. Owocem takiego spojrzenia jest ,[...] specyficzna antropologia o orientacji pneumatologicznej”"27. Jest to nauka o człowieku, który znajduje się w egzystencjalnej relacji do Jezusa Chrystusa, ale także do przemieniającej mocy Ducha Świętego. „Ukazuje jego mozolne dążenie, pomimo upadków, ku temu, aby stać się «nowym stworzeniem»-istotą, na której spoczywa Duch Święty"28. Wskażmy najbardziej charakterystyczne, za naszym

24 Por. W. Hryniewicz, K. Karski, H. Paprocki, Credo..., dz. cyt., s. 223.

Por. W. Hryniewicz, Pascha Chrystusa w dziejach człowieka i wszechświata..., dz. cyt., s. 132, przypis. 207; P. Evdokimov, Prawostawie..., dz. cyt., s. 327-335. „Tak jak każdy człowiek stworzony na obraz Boga jest Jego żywą ikoną, tak ziemska kultura jest ikoną Królestwa Niebieskiego. W chwili wielkiego przejścia Duch Święty, „palec Boży”, dotknie tej ikony i coś pozostanie z niej na zawsze.” P. Evdokimov, Szalona miłość Boga, tłum. M. Kowalska, Białystok 2001, s. 106.

Tematem pneumatologicznego wymiaru antropologii wschodniej interesował się nasz autor przez wiele lat. Pierwszy artykuł pochodzi z roku 1977: Człowiek w mocy Ducha Świętego. Zarys pneumatologii Ojców Wschodnich, „Znak” 29(1977)7-8, s. 775-793. Potem sukcesywnie ukazywały się, m.in.: „Duchowi Świętemu Pan powierzył człowieka”. Rozważania o doświadczeniu Ducha Świętego w chrześcijaństwie wschodnim, [w:] Jan Pawet II, Dominum et vivificantem. Tekst i komentarze, A. Szafrański (red.), Lublin 1994, s. 261-287; Chrystus powierzyt człowieka Duchowi Świętemu. Rozważania nad tradycja wschodnia, „Roczniki Teologiczne” (2004) t. 51, z 2, s. 79-99. W 2012 r. ukazało się obszerne wprowadzenie autorstwa W. Hryniewicza do tłumaczenia jednego z ważniejszych dzieł P. Evdokimova poświęconego tej tematyce. W. Hryniewicz, Duch Święty-mistagog Królestwa Bożego, [w:] P. Evdokimov, Duch Święty w tradycji wschodniej, tłum. M. Żurowska, Poznań 2012, s. 7-25.

27 W. Hryniewicz, Chrystus powierzył człowieka Duchowi Świętemu..., dz. cyt., s. 85.

28 Tamże. 
autorem, momenty prawosławnej antropologii w kontekście pneumatologicznym. Prawdy te, chociaż może nie jest to czasami wprost wypowiedziane, kształtują jego paschalną antropologię.

Pneumatologia prawosławna, podążając za myślą św. Bazylego Wielkiego, specyfikę działania Ducha Świętego wyraża za pomocą przyczynowości udoskonalającej ${ }^{29}$. Duch Święty doprowadza do celu stwórcze działania Ojca i Syna, a stworzenia dzięki Niemu mogą osiągnąć swoje ostateczne spełnienie. W szczególny sposób dotyczy to człowieka, który jako istota teocentryczna jest otwarty i uzdolniony do uczestnictwa w życiu samego Boga. Człowiek został stworzony na obraz Boży, ponieważ został obdarowany przez Stwórcę ,tchnieniem życia”. Ojcowie greccy, opierając się na Septuagincie, często interpretowali słowa, że Bóg stworzonemu człowiekowi „tchnął w jego nozdrza tchnienie życia” w sensie pneumatologicznym, utożsamiając biblijne ,tchnienie" z Duchem Świętym ${ }^{30}$. „Chodzi o stworzenie człowieka takim, aby był zdolny przyjmować tchnienie Ducha osobowego. Zdolność ta zawarta jest niejako potencjalnie już w samym momencie stworzenia człowieka" ${ }^{31}$. W tym znaczeniu zbawcze dzieło Jezusa Chrystusa jest skierowane ku temu, aby człowiek mógł przyjąć Ducha Świętego. W ten sposób urzeczywistnia się pierwotny zamysł Boga wobec człowieka.

Myśl grecka, wyjaśnia W. Hryniewicz, takim sposobem podejmuje ideę, której początki znajdujemy w teologii św. Ireneusza. Biskup Lyonu uczył, że na pełnię człowieczeństwa składają się: ciało, dusza oraz Duch Święty ${ }^{32}$. „Doskonałym człowiekiem jest dopiero zmieszanie i zjednoczenie duszy przyjmującej Ducha Ojca, razem z ciałem, które jest utworzone na obraz Boży"33 - pisał św. Ireneusz w Adversus haereses. Człowiek urzeczywistnia zamierzoną przez Boga doskonałość poprzez przyjęcie Ducha Świętego. Święty Ireneusz nawiązywał do

$29 \quad$ Por. K. Gryz, Antropologia przebóstwienia. Obraz człowieka w teologii prawostawnej, Kraków 2009, s. 119-131; Historia dogmatów, B. Sesboüé (red.), t. 1, B. Sesboüé, J. Wolinski, Bóg zbawienia, tłum. P. Rak, Kraków 1999, s. 239-241; J. N. D. Kelly, Początki doktryny chrześcijańskiej, tłum. J. Mrukówna, Warszawa 1988, s. $195-203$.

30 Por. Z. J. Kijas, Traktat o Duchu Świętym i tasce..., dz. cyt., s. 410; tenże, Przebóstwienie człowieka i świata, Kraków 2000, s.131.

31 W. Hryniewicz, Chrystus powierzyt człowieka Duchowi Świętemu..., dz. cyt., s. 86.

32 Por. tenże, Pascha Chrystusa $w$ dziejach człowieka i wszechświata..., dz. cyt., s. 98; Historia dogmatów, B. Sesboüé (red.),t. 2 V. Grossi, L. F. Ladaria, Ph. Lécrivain, B. Sesboüé, Człowiek i jego zbawienie..., dz. cyt., s. 85-88; J. N. D. Kelly, Poczatki doktryny chrześcijańskiej..., dz. cyt., s. 135-138; H. Pietras, Początki teologii..., dz. cyt., s. 246-252.

$33 \quad$ Cyt za: A. Bober, Antologia Patrystyczna, Kraków 1965, s. 53. 
Antropologia teologiczna

trychotomicznej antropologii św. Pawła, który rozróżniał w nim ducha, dusze oraz ciało (por. 1 Tes 5, 23). Dzieje się to dzięki zesłaniu Ducha Świętego, które dla poszczególnego człowieka aktualizuje się poprzez chrzest. Duch Święty, jako Podobieństwo Boga, prowadzi człowieka do doskonałości, zbawia i przemienia jego dusze oraz ciało, będąc zarazem zasadą jedności człowieka jako duszy i ciała. Człowiek doskonały, według Biskupa Lyonu, został stworzony z ziemi „na obraz” Syna oraz ukształtowany „na podobieństwo” Boże dzięki Duchowi ${ }^{34}$. Człowiekiem doskonałym jest człowiek „duchowy”, jako owoc zjednoczenia Ducha Świętego z ciałem oraz duszą człowieka. Uczestniczenie w Duchu Świętym nie narusza natury człowieka. Więcej, bez Niego człowiek pozostałby niedoskonały, jawiąc się jedynie istotą cielesną i psychiczną ${ }^{35}$. Jedynie obecność i zjednoczenie wszystkich trzech elementów: ciała, duszy i Ducha Świętego, czyni człowieka doskonałym $^{36}$. Wspomnijmy, przywołaną już myśl św. Ireneusza, który nazywa Ducha Świętego „Boską rosą”. Bez niej ludzka egzystencja pozostaje jałową, bezpłodną oraz bezowocną ${ }^{37}$. Obok św. Ireneusza, W. Hryniewicz przywołuje intuicje św. Grzegorza z Nazjanzu, który nauczał o „strumieniu” (apórroos) Ducha Świętego w człowieku, a także św. Symeona Nowego Teologa. Ten ostatni błogosławił Ducha za to, że stał się jedno z jego ludzkim duchem, bez zmieszania i bez zmiany ${ }^{38}$. Tych wypowiedzi teologów wschodnich, podkreśla lubelski profesor, nie można interpretować w sposób tylko metaforyczny. Duch Święty uwalnia osobę ludzka od zależności względem swojej natury, uzdalnia do przykracania samego siebie i otwiera na Boga. „Jako byt otwarty, człowiek w sposób „naturalny” nosi w sobie obraz Boży. Jest w pełni

34 Por. H. Pietras, Początki teologii Kościoła..., dz. cyt., s. 250.

35 „Czym innym jest dech życia, który człowieka czyni psychicznym, a czym innym jest ożywiający Duch, który uczynił go duchowym”. Św. Ireneusz z Lyonu, Bóg w Ciele i Krwi..., dz. cyt., s. 116.

36 Por. W. Hryniewicz, „Duchowi Świętemu Pan powierzyt człowieka”..., dz. cyt., s. 277; tenże, Chrystus powierzył człowieka Duchowi Świętemu..., dz. cyt., s. 86.

37 Por. tenże, Na drodze pojednania. Medytacje ekumeniczne, Warszawa 1998, s. 123-124.

$38 \quad$ Por. tenże, Pascha Chrystusa wdziejach człowieka i wszechświata..., dz. cyt., s.99. Postaci tego wielkiego teologa Hryniewicz poświęcił jeden z rozdziałów swojej książki Na drodze pojednania: Przyzywanie Ducha-bizantyjska pneumatologia Symeona zwanego Nowym Teologiem. W. Hryniewicz, Na drodze pojednania..., dz. cyt., s. 89-102. 
sobą tylko wtedy, kiedy pozostaje we wspólnocie z Bogiem i uczestniczy w Jego życiu. Taki jest jego prawdziwy byt i prawdziwa natura" 39 .

Tradycja wschodnia, systematyzuje nasz autor, opisuje człowieka Antropologia teologiczna jako istotę epikletyczną. Człowiek całym swym istnieniem, choćby był najbardziej grzeszny i zagubiony, nieustannie przyzywa Ducha-Stwórcę. „Jest to pewien rodzaj epiklezy ontologicznej, milczącej i bezsłownej - wołanie z głębi zagubienia i duchowej nędzy" ${ }^{40}$. Wołanie takie może być krzykiem niespełnionego życia, wyrazem tęsknoty wobec własnego ubóstwa czy utraconej nadziei. Jest to wołanie, które jest zdolny usłyszeć tylko Duch Święty, przenikający ukryte głębie ludzkiego serca. Wołanie to, często nieuświadomione, wyraża się w tęsknocie za pięknem, dobrem, harmonią, prawdziwym pokojem.

Duch Święty jest źródłem wszelkiego życia. Jest wszędzie obecny, wszystko przenika, działa w człowieku i w świecie. Jednocześnie nie objawia swojego oblicza. Teologia wschodnia chętnie uczy o kenoezie Ducha. On zawsze wskazuje na Zmartwychwstałego. Duch Chrystusa jest sprawcą piękna przeobrażonego człowieka. Dotknięcie i moc Ducha Świętego odsłania piękno obrazu Bożego w człowieku. Wyraża się ono, m.in., w głębokiej solidarności, naznaczonej współczuciem, ze wszelkim żyjącym stworzeniem. Duch Święty objawia w człowieku Boskie Piękno. Przemieniona ludzka twarz staje się miejscem objawienia Boskiego piękna. „Człowiek przeniknięty przez Ducha oddaje Mu poniekąd swoją własną twarz. W jego ludzkim obliczu przejawia się oblicze samego Ducha" ${ }^{41}$. Duchowe piękno nosi znamię eschatologiczne, antycypując piękno i całą rzeczywistość Bożego świata. Jest to piękno przeobrażonego serca. Tylko Duch Święty może dotknąć i przemienić głębie ludzkiego istnienia oraz jego ducha. On odnawia i upodabnia człowieka do Jezusa Chrystusa, swego Boskiego Prawzoru. Nawet najbardziej grzeszna istota ludzka nosi w sobie przeświadczenie, że jest ikoną Boga. Dlatego jest ona zdolna do nawrócenia i przyjęcia przemieniających darów Ducha.

Duch Święty przenika i przeobraża wszystkich ludzi, także tych, którzy znajdują się poza instytucjonalnymi ramami Kościoła. Jego działanie związane jest $\mathrm{z}$ twórczym działaniem człowieka i różnymi przejawami ludzkiej kultury. Duch jawi się jako źródło nowości, a także spełnienia wszystkich rzeczy stworzonych. Zapowiada i prowadzi do

$39 \quad$ W. Hryniewicz, Na drodze pojednania..., dz. cyt., s. 99; por. tenże, „Duchowi Świętemu Pan powierzyt człowieka”..., dz. cyt., s. 277-278; J. Meyendorff, Teologia bizantyjska. Historia i doktryna, tłum. J. Prokopiuk, Kraków 2007, s. X; $160-163 ; 180-183$.

40 W. Hryniewicz, Chrystus powierzyt człowieka Duchowi Świętemu..., dz. cyt., s. 87.

41 Tamże, s. 87. 
Antropologia teologiczna

ostatecznego przeobrażenia całego Kosmosu. Człowiek poprzez swoją aktywność twórczo współdziała z Boskim Duchem-Stwórcą. Kultura, zwłaszcza jej najważniejsze osiągnięcia, staje się niejako „ikoną” obecności niewidzialnego Ducha, ,[...] teofanicznym przejawem mocy Wcielenia i Pięćdziesiątnicy w świecie stworzonym" ${ }^{42}$. Charakterystycznym wyrazicielem tych intuicji jest myśl S. Bułgakowa. Oczekiwanie na Paruzję jest wyrazem ludzkiego niespełnienia. Jest to aktywne oczekiwanie poprzez twórcze zaangażowanie w przemianę świata. Niesie ono w sobie obietnicę ostatecznego przeobrażenia całego stworzenia mocą Ducha Bożego (por. Rz 8, 22-23). „Oczekiwanie chrześcijan na wielką Paschę Kosmosu i pełnię epifanii Ducha Świętego jest oczekiwaniem aktywnym, pełnym troski i współczucia dla losu całego stworzenia" ${ }^{43}$.

Przestrzenią Ducha, miejscem, gdzie jest On w szczególny sposób obecny i działa, jest ze swej natury Kościól. Ale zawsze Duch pozostaje w Kościele inicjatorem zbawczego działania i nie może być do niego ograniczany. Tradycja wschodnia, podkreśla W. Hryniewicz, uczy, że lepszym stróżem autentyczności wiary w Kościele jest człowiek przeniknięty i przeobrażony mocą Ducha Świętego. To duchowemu, charyzmatycznemu „starcowi” należy bardziej zaufać niż jakiejkolwiek instytucji ${ }^{44}$. Podobnie, gdy życiu Kościoła zagrażał formalizm i skostnienie, pojawiali się tzw. szaleńcy Boży, ,głupi dla Chrystusa” (1 Kor $4,10)$ pełni Ducha, odwagi i wewnętrznej wolności. Oni to pozostając wiecznymi pielgrzymami pobudzali innych do gorliwości i radykalizmu ewangelicznego ${ }^{45}$. Oni stają się świadkami nowości i pełni życia podarowanej przez Ducha Świętego. Stają się szczególnymi świadkami owego powierzenia człowieka Duchowi Świętemu, którego dokonał nasz Pan, Jezus Chrystus ${ }^{46}$.

Słowa kluczowe: antropologia paschalna, pneumatologia, prawosławie, Duch Święty.

42 W. Hryniewicz, Chrystus powierzyt człowieka Duchowi Świętemu..., dz. cyt., s. 91.

Tamże, s. 92.

Por. tamże, s. 89; Prawosławny bp Kalliostos Ware tak pisał na ten temat: „Starzec jest w swej istocie postacią «charyzmatyczną» i profetyczną powołaną do swych zadań poprzez bezpośrednie dzianie Ducha Świętego. Przewodnicy duchowi przyjmują święcenia nie z rąk ludzi, a z ręki Boga. Są wyrażeniem kościoła jako «wydarzenia» raczej, niż kościoła jako instytucji”. K. Ware, Królestwo wnętrza, tłum. W. Misijuk, Lublin 2003, s. 181.

Por. K. Ware, Królestwo wnętrza..., dz. cyt., s. 211-247.

Por. W. Hryniewicz, „Duchowi Świętemu Pan powierzyt człowieka”..., dz. cyt., s. 261. 